\title{
Effect of stocking density on the dynamics of cannibalism in sibling larvae of Perca fluviatilis under controlled conditions
}

\author{
Etienne Baras ${ }^{\mathrm{a}, \mathrm{b}, *}$, Patrick Kestemont ${ }^{\mathrm{c}}$, Charles Mélard ${ }^{\mathrm{b}}$ \\ ${ }^{\mathrm{a}}$ Ethology and Animal Psychology, University of Liège, Belgium \\ ${ }^{\mathrm{b}}$ Aquaculture Research and Education Centre, University of Liège, Belgium \\ ${ }^{\mathrm{c}}$ FUNDP Namur, Unité de Recherches en Biologie des Organismes, Belgium
}

Received 5 February 2002; received in revised form 9 May 2002; accepted 30 June 2002

\begin{abstract}
The effect of stocking density (10, 31.6 and 100 larvae $1^{-1}$; three replicates per treatment) on the day-by-day dynamics of survival, growth and cannibalism was examined in sibling perch larvae reared from eyed-egg stage in 100-1 cages $\left(16 \mathrm{~L}: 8 \mathrm{D}, 20.0 \pm 0.5{ }^{\circ} \mathrm{C}, \mathrm{O}_{2} \geq 6.0 \mathrm{mg} 1^{-1}\right.$; feeding in excess with live Artemia nauplii during the photophase) during the first 3 weeks of exogenous feeding. Larvae unable to achieve the transition to exogenous feeding died in between 7 and 11 days post-hatch. Later, mortality from causes other than cannibalism never exceeded $1 \%$ day ${ }^{-1}$. Cannibalism did not start before days 10-11 and first consisted in the incomplete ingestion of prey attacked tail first, exclusively. This type of cannibalism never caused losses higher than $2.0 \%$ of the initial stock, and ceased after days 16-18. From days 12-14 onwards, differential growth was apparent, and cannibals turned to complete cannibalism of small prey ingested head first, which caused greater losses $(28-53 \%$ of the stock). Increasing the stocking density did not compromise growth and decreased the overall impact of cannibalism through several complementary mechanisms: (i) a postponed emergence of cannibalism, (ii) a lower proportion of cannibals in the population, and (iii) probably a lower rate of cannibalism per capita as predation was complicated and less directed at high stocking density.
\end{abstract}

(C) 2003 Elsevier Science B.V. All rights reserved.

Keywords: Behaviour; Cannibalism; Larvae; Ontogeny; Population density; Perca

* Corresponding author. Aquaculture Research and Education Centre, University of Liège, 10 Chemin de la Justice, B-4500 Tihange, Belgium. Tel.: +32-85-27-41-56, +32-85-23-05-92; fax: +32-85-23-05-92.

E-mail address: E.Baras@ulg.ac.be (E. Baras). 


\section{Introduction}

Cannibalism is a frequent phenomenon in cultured fish (Smith and Reay, 1991; Hecht and Pienaar, 1993; Folkvord, 1997; Baras, 1998; Baras and Jobling, 2002). It is proportionally more frequent among predatory species than in other taxa (esocids, Bry and Gillet, 1980; Giles et al., 1986; Bry et al., 1992; Kucharczyk et al., 1998; clariids, Hecht and Appelbaum, 1988; Baras, 1999; characids: Baras et al., 2000; Gomes et al., 2000; percids: Cuff, 1977, 1980; Loadman et al., 1986; Brabrand, 1995; Mélard et al., 1996a). Larvae catch prey tail first, swallow them progressively up to the head, which is eventually discarded (type I cannibalism: Cuff, 1980). Larvae or juveniles that have gained a growth advantage through the exercise of early cannibalism switch to complete (type II) cannibalism as size heterogeneity develops. Type II cannibalism is ruled by gape-size limitations and can be mitigated by size-sorting, whereas type I cannibalism is not, and can be mitigated exclusively through the adjustment of environmental factors (chiefly stocking density, light, temperature, food and feeding schedule; syntheses in Hecht and Pienaar, 1993; Baras, 1998; Kubitza and Lovshin, 1999; Baras and Jobling, 2002).

Determining the age of fish at the emergence of cannibalism, the respective impact of the two types of predation, and the effect of environmental variables on their intensity are prerequisites to the mitigation of cannibalism in aquaculture. Mitigation of cannibalism is proportionally more important for species in which artificial reproduction is not practised, and for which the production of weaned juveniles represents a substantial part of the total cost of production. Both criteria apply to the Eurasian perch Perca fluviatilis (Tamazouzt et al., 1994; Mélard et al., 1996b). Smily (1952), Il'ina (1973), Spanovskaya and Grygorash (1977), Thorpe (1977) and Brabrand (1995) documented the emergence of cannibalism in perch at an early age. Kestemont et al. (1995) and Mélard et al. (1995, 1996a) reported on its overall impact during the larval and early juvenile stages. Little is known on the actual growth-survival-cannibalism (hereafter, GSC) dynamics of perch, except for studies on small samples in experimental environments (Brabrand, 1995).

This study aimed to characterise the GSC dynamics during the larval and early juvenile stages of the Eurasian perch in production-like conditions, as a function of stocking density. Considering that temperature and provision of food are set for maximising growth in aquaculture environments, light-related factors (day length, light intensity, turbidity) and stocking density are amongst the only factors that can be tailored by aquaculturists. The influence of stocking density on cannibalism in fish has been highlighted on many occasions (Li and Mathias, 1982; Degani and Levanon, 1983; Giles et al., 1986; Hecht and Appelbaum, 1988; van Damme et al., 1989; Haylor, 1991; Kaiser et al., 1995; Mélard et al., 1996a; Kucharczyk et al., 1998; Baras et al., 1999). Little is known however whether stocking density affects the emergence of cannibalism, the number of cannibals in the population and/or the dynamics of cannibalism (Kucharczyk et al., 1998).

\section{Material and methods}

All fish used in this experiment were siblings originating from a single egg ribbon (circa 66,500 eggs) spawned by wild breeders in the Lake of Robertville (Eastern 
Belgium). The ribbon was collected on 30 April 1998, and was transferred into the experimental hatchery of the Aquaculture Station of the University of Liège (Tihange, Belgium). Eggs were incubated onto trays at $15-16{ }^{\circ} \mathrm{C}$ until eyes of embryos were visible. Two days before hatching, four samples of eggs (circa $1 \mathrm{~g}$ ) were weighed (nearest $\mathrm{mg}$ ) and counted in order to determine the mean weight of eggs $(8.7 \pm 0.4 \mathrm{mg})$, and the survival rate at this stage ( $\geq 99 \%$ in all four samples). On the eve of hatching, nine groups of eggs were weighed (nearest $0.1 \mathrm{~g}$ ), and transferred onto trays that were installed inside 100-1 floating cages (mesh size: $100 \mu \mathrm{m}$, PVC bottom plate) in an independent recirculating system at $16{ }^{\circ} \mathrm{C}$. This was done because larvae of perch are more delicate to handle and count than eggs, especially when regularly arranged in a ribbon. Three stocking densities, with three replications per treatment, were evaluated, using logarithmic steps between densities (i.e. 1000, 3163 and 10,000 eggs per cage, hereafter treatments L, M and H [low, medium and high], respectively).

Within the first $24 \mathrm{~h}$, water temperature was warmed progressively from 16.0 to $20.0 \pm 0.5{ }^{\circ} \mathrm{C}$, then was automatically regulated at this value for the rest of the experiment. The illumination regime was set at 16L:8D (light from 0600 to $2200 \mathrm{~h}$ ), after Jourdan (1999) demonstrated the positive correlation between day length and the survival of perch larvae. The trays were removed when all embryos had hatched (delay between earliest and latest hatching eggs: $49 \mathrm{~h}$; mean body weight of embryos: $0.85 \mathrm{mg}$ ). Food distribution started on the next day (hereafter, day 1) and extended over 3 weeks. Larvae were fed in excess with live brine shrimp nauplii (45.2\% protein, $21 \%$ lipid content) that were distributed with a peristaltic pump (Watson Marlow, model $202 \mathrm{~S}$ ) during daylight hours (10 periods of $10 \mathrm{~min}$ at 90 -min intervals, starting from $0800 \mathrm{~h}$ ). The food rations were incremented each day (i.e. from $1 \mathrm{mg}$ per fish on day 1 to $80 \mathrm{mg}$ per fish on day 21), in order that fish were fed in excess throughout the experiment. In between the first two feeding periods of each day, the bottom plate of each cage was siphoned. Dead fish were separated from faeces and wasted feed. Tail-off larvae or fish heads were regarded as victims of type I cannibalism, and were counted separately from other dead fish.

On feeding days 7 and 14, a sample of 25 (L) or 50 fish ( $\mathrm{M}$ and $\mathrm{H}$ ) was collected in each cage in order to measure size heterogeneity. On day 22, no food was distributed. The cages were emptied and all surviving larvae were counted. A sample of 100 randomly selected fish was measured in each group when the number of survivors exceeded this value. All large (i.e. about twice the size of the smallest fish within the sample; Brabrand, 1995; Mélard et al., 1996a) individuals, which were deemed to have cannibalistic tendencies, were counted and measured individually to the nearest $0.1 \mathrm{mg}$. Additional samples of live fish were collected in 2-1 buckets on days 7,14 and 18 in order to estimate the survival rates until these days. The volume of water was measured to the nearest 0.011 , then fish were counted and released into the cages (three samples per cage).

The losses to type II cannibalism were calculated as follows. The theoretical survival rate was obtained by subtracting from the initial number of fish, the running sums of dead fish (both intact and truncated) collected each day. The actual survival rate was estimated from volumetric estimates (days 7, 14 and 18) or counts (day 22) of survivors. Type II cannibalism was deemed to have started when the former was outside the $95 \%$ confidence 
interval of the latter. The effect of stocking density on mortality, type I and type II cannibalism, and the proportion of cannibals at the end of the study was analysed by contingency table analysis. The body weights of perch larvae on days 7, 14 and 21 were compared with one-way analyses of variance (ANOVA) and Scheffe $F$-tests. Null hypotheses were rejected at $P<0.05$.

\section{Results}

At the end of the study, survival was significantly higher at the highest stocking density (H, Table 1). All fish in cage L3 died within the first 20 rearing days (Fig. 1), possibly as a result of a pathological outbreak, and this group was not taken into account for any statistical comparison in this article. Except for this, mortality showed unimodal dynamics, with a sharp peak $\left(8.5-17.6 \%\right.$ day $\left.{ }^{-1}\right)$ on day 7 or 8 , and a curvilinear decrease until day 11 or 12 . Frequency distributions of fish body weight on day 7 were bimodal, with about $30 \%$ of the fish showing no weight gain since hatching (Fig. 2). Most dead larvae collected from day 7 to day 12 had slender bodies and weighed less than $1.0 \mathrm{mg}$. The frequency distributions of fish body weights on day 14 had become unimodal, and contained no or very few fish weighing less than $1 \mathrm{mg}$. These observations support the idea that mortality during this period affected essentially the smallest individuals, which were probably nonfeeders. Beyond day 12 , these losses were always $<1.0 \%$ day $^{-1}$, except in cage L3. Over the 21-day

Table 1

Effect of stocking density on the mortality, cannibalism and growth of sibling perch reared over 21 days in 100-1 floating cages at $20.0 \pm 0.5{ }^{\circ} \mathrm{C}$ under $16 \mathrm{~L}: 8 \mathrm{D}$

\begin{tabular}{llll}
\hline Density & Low $(\mathrm{L})$ & Medium $(\mathrm{M})$ & High $(\mathrm{H})$ \\
\hline Initial numbers of eggs $\left(N_{\mathrm{i}}\right)$ & 1000 & 3163 & 10,000 \\
Final numbers of juveniles $\left(N_{\mathrm{f}}\right)$ & $148 \pm 24$ & $596 \pm 147$ & $2014 \pm 571$ \\
Total survival $(\%)$ & $14.75 \pm 2.35^{\mathrm{a}}$ & $18.87 \pm 4.64^{\mathrm{ab}}$ & $20.14 \pm 5.71^{\mathrm{b}}$ \\
Losses to type I cannibalism $\left(\% N_{\mathrm{i}}\right)$ & $1.40 \pm 0.30^{\mathrm{a}}$ & $1.50 \pm 0.20^{\mathrm{a}}$ & $1.39 \pm 0.75^{\mathrm{a}}$ \\
Losses to type II cannibalism $\left(\% N_{\mathrm{i}}\right)$ & $53.15 \pm 9.25^{\mathrm{a}}$ & $28.04 \pm 3.04^{\mathrm{b}}$ & $34.37 \pm 8.29^{\mathrm{ab}}$ \\
'Natural' mortality $\left(\% N_{\mathrm{i}}\right)$ & $30.70 \pm 6.60^{\mathrm{a}}$ & $51.65 \pm 4.50^{\mathrm{b}}$ & $44.10 \pm 5.66^{\mathrm{ab}}$ \\
Cannibals $(N)$ on day 21 & $3.0 \pm 0.0^{\mathrm{a}}$ & $4.3 \pm 1.2^{\mathrm{b}}$ & $6.0 \pm 3.2^{\mathrm{ab}}$ \\
$\left(\% o N_{\mathrm{i}}\right)$ & $3.0 \pm 0.0^{\mathrm{a}}$ & $1.4 \pm 0.4^{\mathrm{b}}$ & $0.6 \pm 0.3^{\mathrm{c}}$ \\
$\left(\% o N_{\mathrm{f}}\right)$ & $20.9 \pm 3.3^{\mathrm{a}}$ & $9.0 \pm 4.5^{\mathrm{b}}$ & $4.2 \pm 2.4^{\mathrm{b}}$ \\
Body weight (mean, mg $\pm \mathrm{CV} \%)$ & $1.2( \pm 57.07 \%)^{\mathrm{a}}$ & $1.2( \pm 46.94 \%)^{\mathrm{a}}$ & $1.6( \pm 46.22 \%)^{\mathrm{b}}$ \\
day 7 & $4.0( \pm 57.02 \%)^{\mathrm{a}}$ & $3.5( \pm 46.07 \%)^{\mathrm{a}}$ & $4.3( \pm 53.92 \%)^{\mathrm{a}}$ \\
day 14 & $7.3( \pm 46.22 \%)^{\mathrm{a}}$ & $9.7( \pm 43.11 \%)^{\mathrm{b}}$ & $11.2( \pm 36.48 \%)^{\mathrm{c}}$ \\
day 22 (non-cannibal fish) & $51.2( \pm 25.13 \%)^{\mathrm{a}}$ & $74.5( \pm 40.14 \%)^{\mathrm{b}}$ & $68.1( \pm 24.19 \%)^{\mathrm{ab}}$ \\
day 22 (cannibals) & & & \\
\hline
\end{tabular}

Except when additional precision is given, values are means \pm S.E.M. of three replicates. For each line of the table, values sharing one common superscript are not significantly different whereas other comparisons differ at $P<0.05$ (contingency table analyses for survival and cannibalism, ANOVA and Scheffe $F$-tests for body weights). $N_{\mathrm{i}}$ and $N_{\mathrm{f}}$ are the initial and final (day 22) numbers of fish, respectively. CV is the coefficient of variation. 


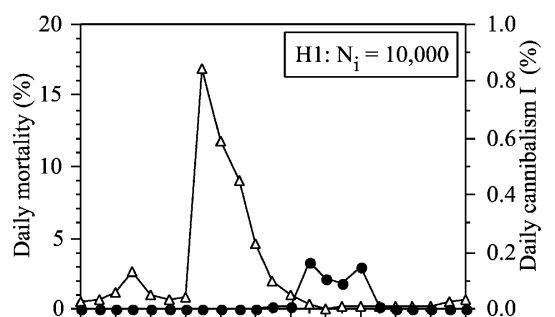

$\begin{array}{llllllllllll}0 & 2 & 4 & 6 & 8 & 10 & 12 & 14 & 16 & 18 & 20 & 22\end{array}$

Time (days)

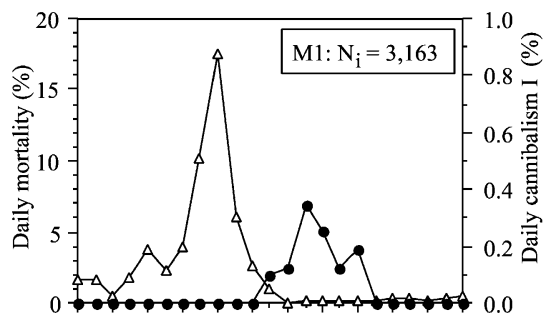

$\begin{array}{llllllllllll}0 & 2 & 4 & 6 & 8 & 10 & 12 & 14 & 16 & 18 & 20 & 22\end{array}$

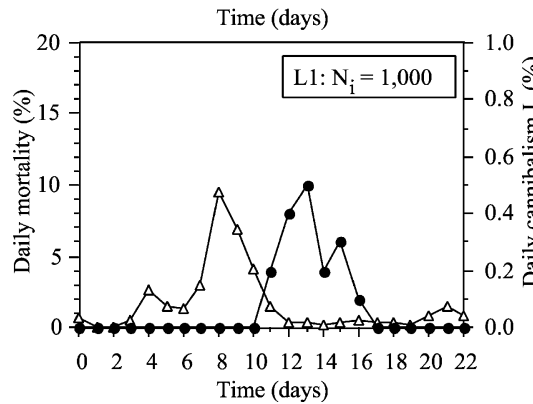

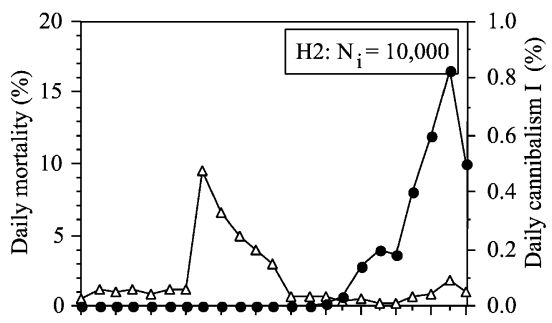

$\begin{array}{llllllllllll}0 & 2 & 4 & 6 & 8 & 10 & 12 & 14 & 16 & 18 & 20 & 22\end{array}$

Time (days)
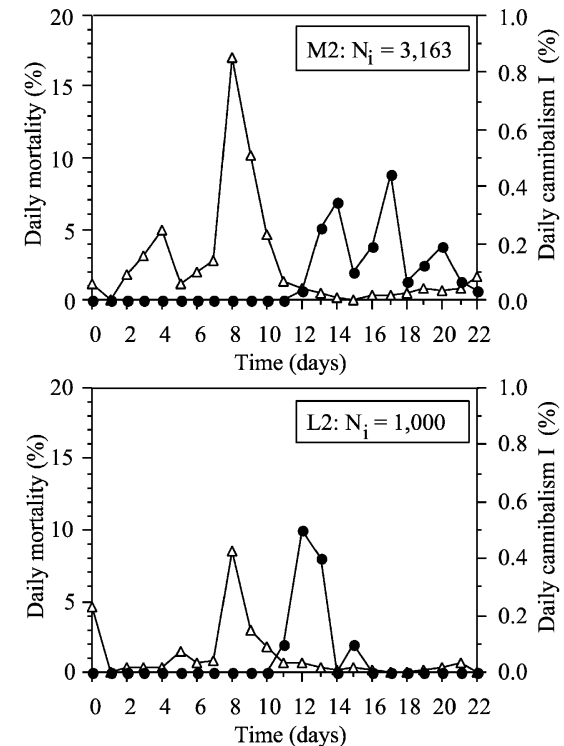

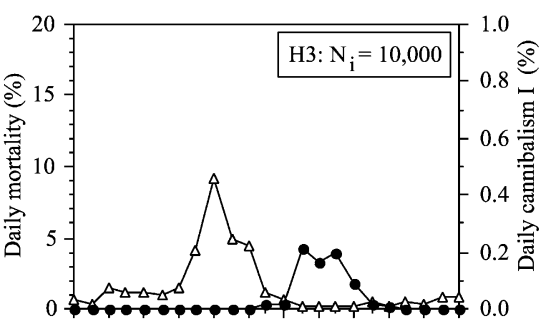

$\begin{array}{llllllllllll}0 & 2 & 4 & 6 & 8 & 10 & 12 & 14 & 16 & 18 & 20 & 22\end{array}$ Time (days)

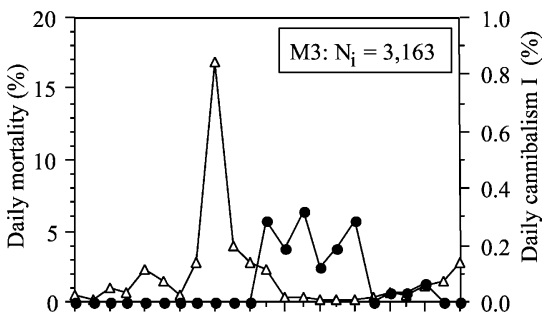

$\begin{array}{llllllllllll}0 & 2 & 4 & 6 & 8 & 10 & 12 & 14 & 16 & 18 & 20 & 22\end{array}$ Time (days)

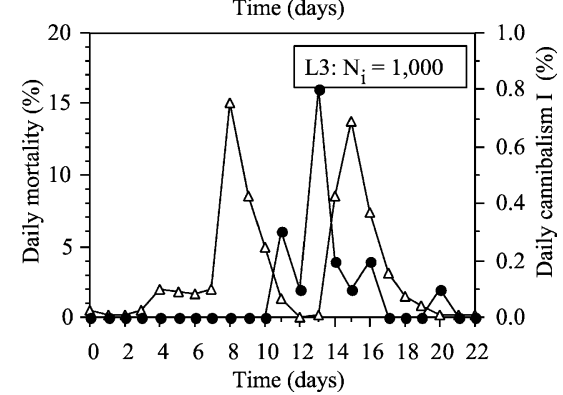

Fig. 1. Variation of daily rates of type I cannibalism (closed circles) and mortality from starvation or other causes (open triangles) among sibling larvae of Eurasian perch, depending on stocking density. $N_{\mathrm{i}}$ is the initial of eggs (100-1 floating cages at $20.0^{\circ} \pm 0.5^{\circ} \mathrm{C}$, under $\left.16 \mathrm{~L}: 8 \mathrm{D}\right)$, and day 0 is the time when all embryos had hatched. 

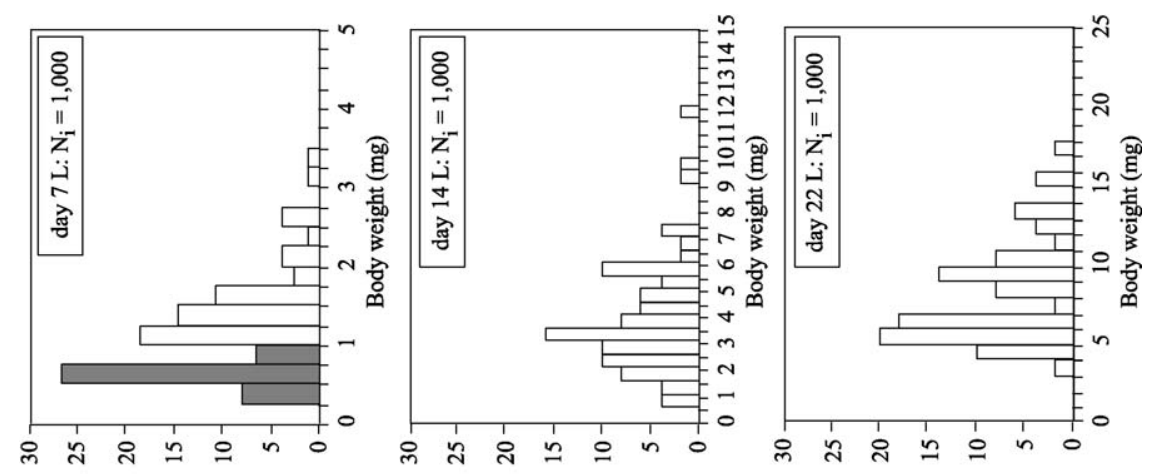

(\%) Кэuənbəد

(\%) Кэuənbəد,

(\%) Kouวnbaม
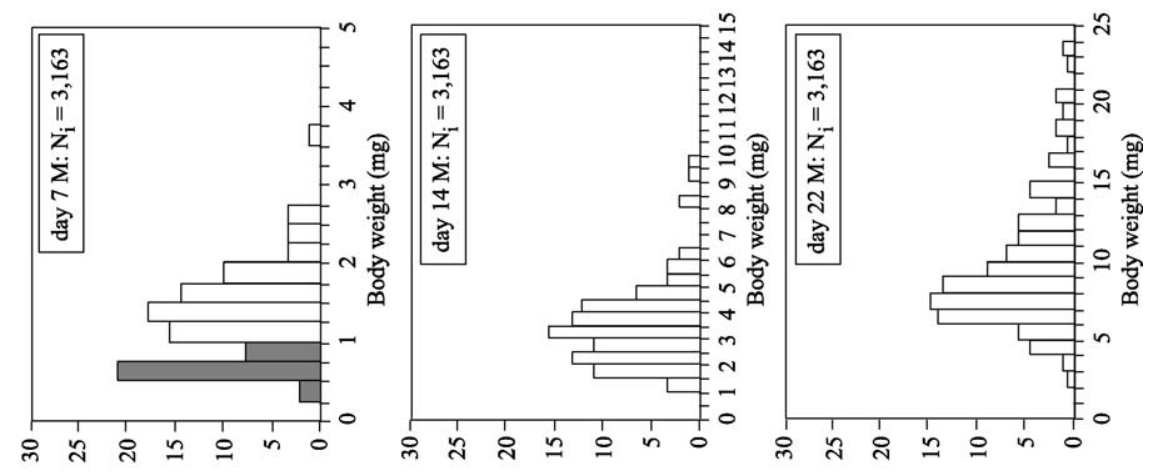

(\%) Кэuənbəد

(\%) KouənbarH

(\%) Kouวnbar

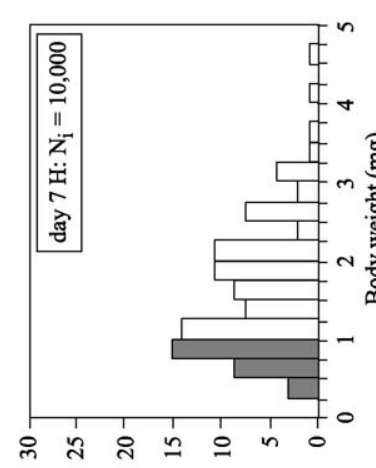

(\%) KouənbəxH
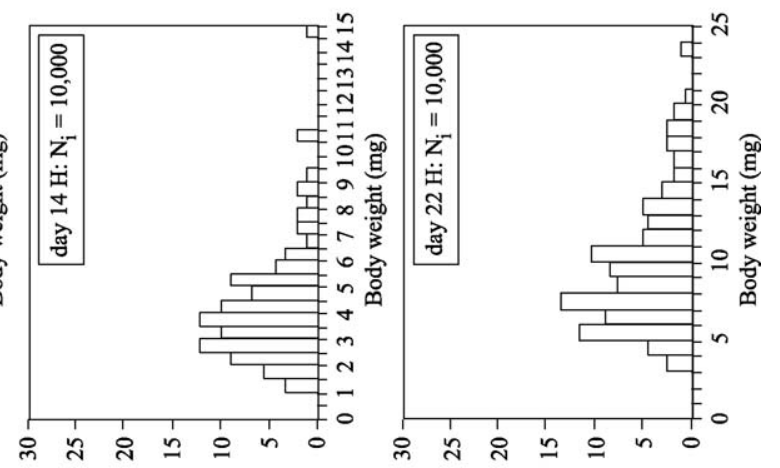

(\%) KouənbəدH

(\%) Кวuənbว 
rearing period, deaths from causes other than cannibalism amounted to over $30 \%$ of the initial stock in all three treatments, with the highest impact in treatment $\mathrm{M}(51.7 \%$, Table 1).

Truncated fish were observed first on day 11, suggesting that type I cannibalism had not been exerted by larvae younger than 10 days. It peaked in between days 12 and 15, then vanished in most groups after day 16. A notable exception to this pattern was group $\mathrm{H} 2$, which showed the lowest mortality rate of all groups, and where type I cannibalism persisted until the end of the experiment (Fig. 1). On average, losses to type I cannibalism were low ( $\leq 1.5 \%$ of initial stock), and did not differ significantly between stocking densities (Table 1). However, type I cannibalism emerged, and peaked slightly earlier in treatments $\mathrm{L}$ compared to treatments $\mathrm{M}$ and $\mathrm{H}$ (Figs. 3 and 4).

Volumetric counts of the numbers of perch on days 7 and 14 were consistent with the numbers of survivors that were estimated from losses to mortality and to type I cannibalism, suggesting that type II cannibalism had been insignificant until this age (Fig. 3). By contrast, counts on days 18 and 22 were significantly lower than the estimated numbers of survivors, suggesting that type II cannibalism had started becoming intense in between days 14 and 18. This conclusion is supported by the finding that the coefficient of variation (CV) of the mean body weight was high until day 14 inclusive, and decreased from day 14 to day 22 (Table 1), when the smallest individuals were removed from the population by the cannibals. It is also supported by some observations of suffocated cannibals, with the head of the prey stuck in their gut, from day 16 onwards (exclusively in groups $\mathrm{H} 1$ and $\mathrm{H} 3$ ). This was seen in all cages, except for H2, where type I cannibalism was still intense on these days. As was seen with type I cannibalism, type II cannibalism started earlier at low stocking density than in other groups. This was probably the reason why the total loss to type II cannibalism in treatments L was greater than in treatments $\mathrm{M}$ and $\mathrm{H}$. Similarly, the final (day 22) proportions of large juveniles deemed to have cannibalistic tendencies differed significantly between treatments, and were inversely proportional to stocking density (Table 1). It is worth noticing that no single fish of group $\mathrm{H} 2$ was identified as a potential cannibal, despite the fact that the impact of type II cannibalism was estimated at $23.2 \%$ of the initial stock in this particular group. This apparent paradox could be due to cannibals 'tracking the population', and consuming prey as soon as they were proportionally small enough to be consumed.

Perch larvae grew at a relatively slow rate in all groups $\left(<13 \%\right.$ day $\left.{ }^{-1}\right)$. Nevertheless, growth rates and size heterogeneity were significantly influenced by the initial stocking density. Final body weight was greater and size heterogeneity was lower in treatments $\mathrm{H}$ than in other treatments (Table 1). No such differences were seen on days 7 and 14,

Fig. 2. Body weight frequency distributions of perch larvae aged 7, 14 and 21 days, depending on stocking density. Values are the means of three replicates for the three stocking densities. Distributions on days 7 and 14 were obtained from one sample of $25\left(N_{\mathrm{i}}=1000\right)$ or 50 fish $\left(N_{\mathrm{i}} \geq 3163\right)$ in each group, whereas the distributions on day 22 took into account all surviving fish, except for the individuals assumed to be potential cannibals (Table 1). Closed bars on graphs at day 7 are fish showing no positive growth, and deemed to starve during the next days. 

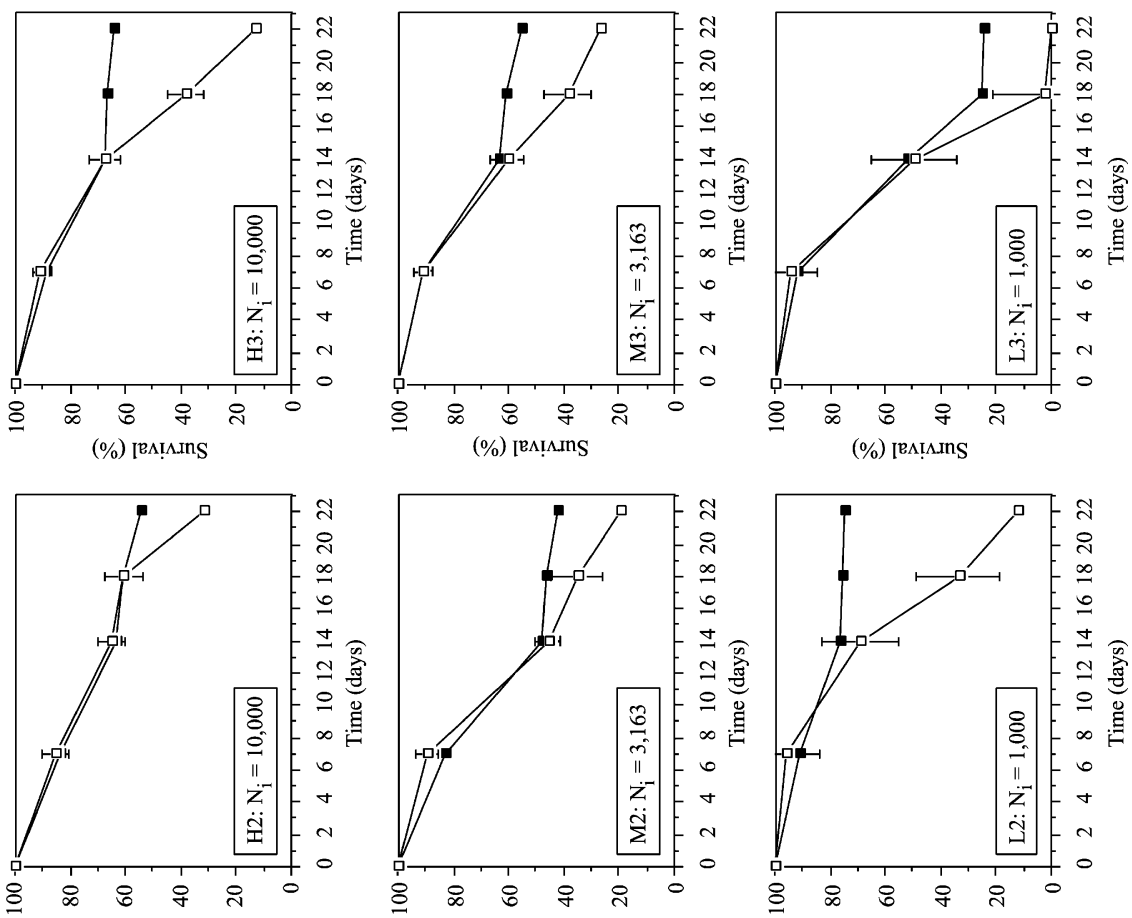

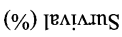
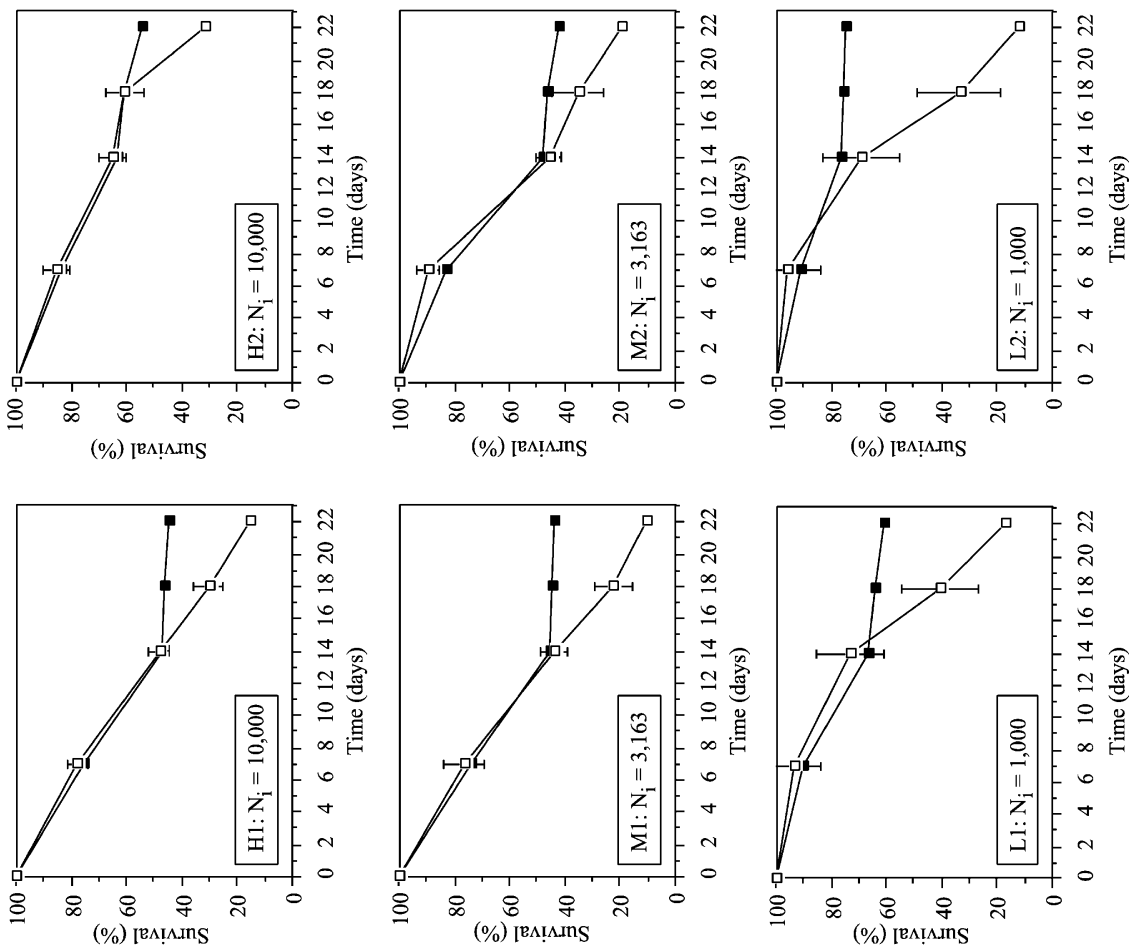


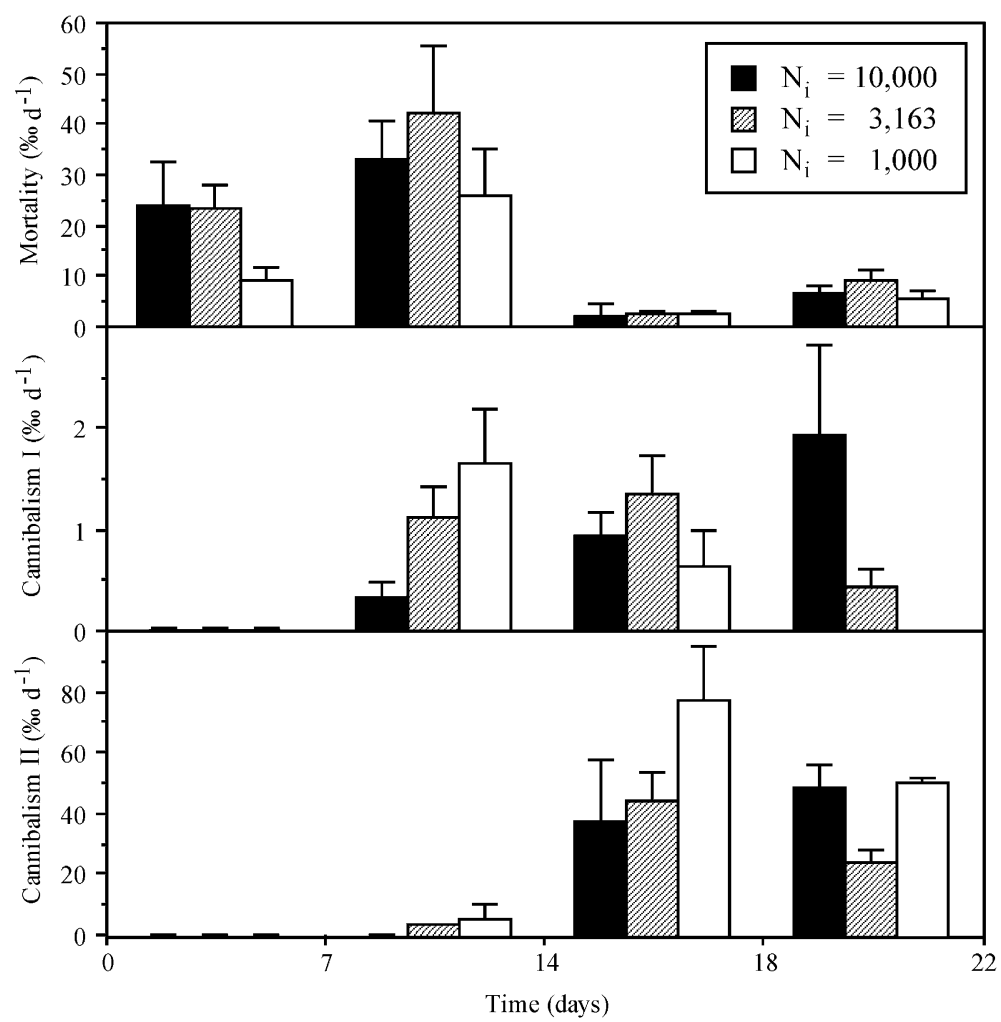

Fig. 4. Dynamics of mortality and cannibalism ( $\mathrm{I}=$ incomplete ingestion, $\mathrm{II}=$ complete ingestion) during the ontogeny of perch, depending on stocking density. Values and error bars are the means \pm S.E.M. of three replicates.

suggesting that most of the differences emerged during the period when type II cannibalism was most intense (days 14-21).

\section{Discussion}

As in other percomorphs (e.g. striped bass Morone saxatilis, Tsai, 1991), a substantial proportion of perch larvae is unable to prey on Artemia nauplii, and requires smaller food items (e.g. rotifers, small size Artemia; Mélard et al., 1996a; Vlavonou et al., 1999). Kestemont et al. (1996) estimated that this proportion ranged from $30 \%$ to $40 \%$. Jourdan

Fig. 3. Comparison between the survival rates of perch larvae, as estimated from the daily counts of dead larvae and victims of type I cannibalism (closed squares), and those deduced from volumetric estimates (open squares; days $7,14,18$ ) or fish counts (day 22). Volumetric estimates of the number of survivors were obtained from three samples of circa 21 in each group. Error bars are the $95 \%$ confidence intervals of volumetric estimates. A difference between the two estimates indicates that type II cannibalism has caused significant losses since the last examination. 
(1999) and Vlavonou et al. (1999) reported that perch larvae that were apparently unable to feed on Artemia nauplii died in between 6 and 11 day post-hatch, and similar mortality dynamics were obtained during starvation experiments at the same temperature as here (Abi-Ayad, 1998). This supports the idea that the early mortality of perch larvae during this study reflected small fish dying of hunger. Beyond day 11, cannibalism contributed presumably to eliminating the few remaining individuals weakened by starvation.

Cannibalistic behaviour in this experiment was observed first in 10-day-old fish. This is consistent with the findings of Brabrand (1995), who stated that perch do not exert cannibalism at larval stage IV $(7.2 \mathrm{~mm}$ and $<2 \mathrm{mg}$; after the classification of Konstantinov, 1957), whereas they do from larval stage V (10.5 $\mathrm{mm}$ and $6 \mathrm{mg})$ onwards. This is much earlier than in most other temperate species (e.g. pike Esox lucius; Giles et al., 1986; Bry et al., 1992; koi carp Cyprinus carpio, van Damme et al., 1989; sea bass Dicentrarchus labrax, Katavic et al., 1989; yellowtail Seriola quinqueradiata, Sakakura and Tsukamoto, 1996), but slightly later than in other percids (walleye Stizostedion vitreum: Cuff, 1977; Loadman et al., 1986) and percichtyids (striped bass M. saxatilis: Braid and Shell, 1981) at similar temperatures.

Brabrand (1995) observed that perch could consume siblings tail first or head first. Here, perch larvae started consuming their prey tail first exclusively, probably because size heterogeneity was initially low, and did not permit cannibals to find prey that were small enough to be swallowed whole. Later, size heterogeneity increased, partly as a result of early cannibalism. Fish prey have a higher content of digestible nutrients than plankton prey (Meffe and Crump, 1987; Kubitza and Lovshin, 1999), so fish feeding totally or partly on conspecifics generally grow faster than those feeding exclusively on plankton prey (Baras and Jobling, 2002), and this is precisely the case in the Eurasian perch (Brabrand, 1995). Increasing size heterogeneity facilitated the exercise of type II cannibalism, which is determined by gape-size limitations. The reasons behind the abandonment of type I cannibalism in the Eurasian perch are probably manifold, and similar to those invoked for other species: a greater difficulty of capturing tail first prey with increasing swimming capacities (e.g. Li and Mathias, 1982) and a greater risk of exposure to other cannibals (e.g. Baras et al., 2000) or kleptoparasites (e.g. Nilsson and Bronmark, 1998) when prey increase in size. Brabrand (1995) precisely found that cannibals of Eurasian perch were less successful while trying to catch their prey tail first. Another reason behind the shift to complete cannibalism in perch and other Acanthopterygians is the development of spiny fin-rays. As soon as spiny rays develop, prey can no longer be ingested tail first to avoid damage the mouth and gut of the cannibals. This implies that prey are smaller relative to cannibals than were those for type I cannibalism, and that the per capita impact of cannibalism increases after the shift to type II cannibalism (see also Baras, 1999; Baras et al., 2000). The earlier the emergence of type I cannibalism, the earlier the increase in size heterogeneity and shift to type II cannibalism, and the greater the overall impact of cannibalism. This functional interpretation accounts for why cannibalism was more intense at the lowest stocking density, where type I cannibalism emerged earlier than at higher stocking densities.

The negative correlation between stocking density and growth in perch at high stocking density is consistent with the results of large-scale 'black-box' experiments by Mélard et al. (1996a), and can be accounted for by several complementary factors. Uematsu and 
Takamori (1976) put forward the role of social facilitation of feeding in the medaka Oryzias latipes (i.e. greater amounts of food consumed by individuals at higher stocking density). Hecht and Uys (1997) found that sharptooth catfish consumed less food when stocked at low density, and they hypothesised that the motivation to maintain a territory was stronger than the motivation to forage in these circumstances. Similar considerations may apply here: perch larvae were observed shoaling at the intermediate and high stocking density, whereas they were dispersed at the lowest stocking density. Whichever the exact reason, increasing the stocking density resulted in faster growth and lower size heterogeneity (see also Grant, 1993, 1997 for a discussion on the effect of density on dominance hierarchies, and Kestemont et al., in press for a review of factors that affect size heterogeneity among Eurasian perch larvae).

An increase in stocking density results in a greater probability of encounter between a cannibal and potential prey. In species or life stages that exert a contact-and-consume predation, this leads to increased cannibalism (e.g. walleye: Cuff, 1980; Li and Mathias, 1982; Loadman et al., 1986; catfishes: Haylor, 1991; characids: Baras et al., 2000; Gomes et al., 2000). In visually orientated species, cannibalism can be complicated when the predator is confronted to a large number of targets, which may cause a perceptual confusion effect and make prey selection less efficient. For example, Kucharczyk et al. (1998) observed that the cannibalistic attacks of northern pike were less successful when population density was high. The confusion brought about by the multiplicity of targets may also cause predators to misestimate the relative size of their prey and direct their attacks towards prey that are slightly too large for their gape. Perch possesses spiny finrays that make regurgitation impossible, so cannibals that consume excessively large prey eventually suffocate. The finding that suffocated perch cannibals were observed at the highest stocking density exclusively, supports this interpretation.

Cannibals at high stocking density probably had a lower impact per capita and could exert cannibalism over a shorter period than at lower densities. The number of fish identified as cannibals at the end of the study was proportional to stocking density, but the proportion of cannibals relative to the initial number of fish was negatively correlated to stocking density. A similar relationship was observed by Mélard et al. (1996a), who hypothesised that a minimum territory size was necessary for the expression of type II cannibalism. As a corollary, the maximum number of cannibals that can be 'hosted' by an environment is strongly influenced by the dimensions of the environment, so increasing the initial stocking density may serve to reduce the proportion of cannibals, and thus the impact of cannibalism. The latter argument should be considered with caution, at least when the proportion of cannibals is determined from the examination of size distributions at the end of a rearing period. Such an information is of great value for predicting forthcoming cannibalism, but is of limited value for understanding how intense cannibalism has been until then (Baras and Jobling, 2002). Cannibalism impacts on size heterogeneity, and group $\mathrm{H} 2$, where no single fish was identified as a cannibal despite cannibalism had eliminated over $30 \%$ of the stock, is a good example of this.

All in all, cannibalism caused the elimination of $29.5 \%$ to $54.5 \%$ of the initial stock, depending on stocking density. These losses are higher than in a series of other experiments with perch. We cannot rule out the hypothesis that cannibalism had been facilitated by the hatching time extending over $49 \mathrm{~h}$ in this experiment. Differential hatching generally results 
in greater initial size heterogeneity, which is likely to facilitate cannibalism (e.g. larvae of sharptooth catfish Clarias gariepinus; Baras and d'Almeida, 2001). However, Kestemont et al. (in press) report that cannibalism in perch is as intense among siblings hatched within 24 $\mathrm{h}$ as among siblings hatched over $48 \mathrm{~h}$. The difference between perch and other fish species in which differential hatching has been found to influence cannibalism, probably relates to the times of emergence of cannibalism with respect to the dynamics of mortality of starving fish (Baras and Jobling, 2002). If cannibalism starts early during the ontogeny, small or deformed fish are the trigger to cannibalism. On the contrary, if cannibalism starts after small or deformed larvae have starved, as is the case for perch, initial size heterogeneity has less influence on the dynamics of cannibalism. Instead, it is probable that cannibalism in this particular experiment has been facilitated by young perch being fed exclusively with brine shrimp nauplii, which have a lower energy content than formulated feed (Kubitza and Lovshin, 1999; Lee and O'Bryen, 2001). Cannibals obtain a proportionally greater advantage over siblings feeding on brine shrimp than over those feeding on formulated feed (Baras and Jobling, 2002), so cannibalism can cause greater losses if the distribution of plankton prey is prolonged for longer than necessary.

\section{Conclusion}

This study provided evidence that the decrease of cannibalism among perch under increasing stocking density resulted from a combination of factors (lower proportion of cannibals, lower per capita impact, delayed emergence of cannibalism). This finding, together with the observation that type I cannibalism - which cannot be mitigated by size grading - has a minor impact in perch, is an encouraging result for the development of perch aquaculture. Nevertheless, type II cannibalism in perch may become intense at an age (14-18-day post-hatch) and size $(<20 \mathrm{~mm})$ when fish are still too small for manual or mechanical size-sorting. Future research efforts should aim at improving the growth of perch during the early life stages, as this would postpone the onset of complete cannibalism and enable aquaculturists to sort fish at a younger age, thereby decreasing the overall losses to cannibalism. Formulated feed has a higher energy content than plankton prey, and the determination of the cut-off sizes or age at which perch larvae can be weaned is a priority, for reducing both cannibalism and feeding costs. In view of the dynamics of cannibalism observed here, it would be worthwhile to try weaning perch larvae at 14-16day post-hatch at $20{ }^{\circ} \mathrm{C}$, since this is the time when type II cannibalism starts becoming intense. Preliminary experiments indicate that this is indeed feasible and that it yields survival and growth rates similar to, or better than those of fish weaned at an older age (Gielen et al., unpublished).

\section{Acknowledgements}

This study was part of European Union contract FAIR CT96-1572 (DG XII-XIV/C2). The authors wish to thank Electrabel for supporting the fish culture programmes at the University of Liège. E. Baras is a research associate of the Belgian FNRS. 


\section{References}

Abi-Ayad, S.M.E.A., 1998. Etude expérimentale de la biologie de la reproduction de la perche fluviatile (Perca fluviatilis). Effet de la composition en acides gras de la série (n-3) de l'alimentation sur la qualité des œufs et des larves. PhD Thesis, University of Liège, $147 \mathrm{pp}$.

Baras, E., 1998. Biological bases of cannibalism in fish. Cah. Éthol. 18, 53-98 (Fr)

Baras, E., 1999. Sibling cannibalism among juvenile vundu under controlled conditions: I. Cannibalistic behaviour, prey selection and prey size-selectivity. J. Fish Biol. 54, 82-105.

Baras, E., d'Almeida, A.F., 2001. Size heterogeneity prevails over kinship in shaping cannibalism among larvae of sharptooth catfish Clarias gariepinus. Aquat. Living Resour. 14, 251-256.

Baras, E., Jobling, M., 2002. Dynamics of intracohort cannibalism in cultured fishes. Aquac. Res. 33, $461-479$

Baras, E., Tissier, F., Philippart, J.-C., Mélard, C., 1999. Sibling cannibalism among juvenile vundu under controlled conditions: II. Effect of body weight and environmental variables on periodicity and the intensity of type II cannibalism. J. Fish Biol. 54, 106-118.

Baras, E., Ndao, M., Maxi, M.Y.J., Jeandrain, D., Thomé, J.-P., Vandewalle, P., Mélard, C., 2000. Sibling cannibalism in dorada under experimental conditions: I. Ontogeny, dynamics, bioenergetics of cannibalism and prey size selectivity. J. Fish Biol. 57, 1001-1020.

Brabrand, Å., 1995. Intracohort cannibalism among larval stages of perch (Perca fluviatilis). Ecol. Freshw. Fish 4, $70-76$.

Braid, M.R., Shell, E.W., 1981. Incidence of cannibalism among striped bass fry in an intensive culture system. Prog. Fish-Cult. 43, 210-212.

Bry, C., Gillet, C., 1980. Réduction du cannibalisme précoce chez le brochet (Esox lucius) par isolement des fratries. Bull. Fr. Piscic. 277, 142-153.

Bry, C., Basset, E., Rognon, X., Bonamy, F., 1992. Analysis of sibling cannibalism among pike, Esox lucius, juveniles reared under semi-natural conditions. Environ. Biol. Fishes 35, 75-84.

Cuff, W.R., 1977. Initiation and control of cannibalism in larval walleyes. Prog. Fish-Cult. 39, $29-32$.

Cuff, W.R., 1980. Behavioral aspects of cannibalism in larval walleye, Stizostedion vitreum. Can. J. Zool. 58, $1504-1507$.

Degani, G., Levanon, D., 1983. The influence of low density on food adaptation, cannibalism and growth of eels (Anguilla anguilla (L.)). Bamidgeh 35, 53-60.

Folkvord, A., 1997. Ontogeny of cannibalism in larval and juvenile fishes with special emphasis on Atlantic cod. In: Chambers, R.C., Trippel, E.A. (Eds.), Early Life History and Recruitment in Fish Populations. Chapman \& Hall, London, pp. 251-278.

Giles, N., Wright, R.M., Nord, M.E., 1986. Cannibalism in pike fry, Esox lucius L.: some experiments with fry densities. J. Fish Biol. 29, 107-113.

Gomes, L.C., Baldisserotto, B., Senhorini, J.A., 2000. Effect of stocking density on water quality, survival, and growth of larvae of the matrinxã, Brycon cephalus (Characidae), in ponds. Aquaculture 183, $73-81$.

Grant, J.W.A., 1993. Whether or not to defend? The influence of resource distribution. Mar. Behav. Physiol. 23, $137-153$.

Grant, J.W.A., 1997. Territoriality. In: Godin, J.-G.J. (Ed.), Behavioural Ecology of Teleost Fishes. Oxford Univ. Press, Oxford, pp. 81-103.

Haylor, G.S., 1991. Controlled hatchery production of Clarias gariepinus (Burchell, 1822): growth and survival of fry at high stocking density. Aquac. Fish. Manage. 22, 405-422.

Hecht, T., Appelbaum, S., 1988. Observations on intraspecific aggression and coeval sibling cannibalism by larval and juvenile Clarias gariepinus (Clariidae: Pisces) under controlled conditions. J. Zool. (Lond.) 214, $21-44$.

Hecht, T., Pienaar, A.G., 1993. A review of cannibalism and its implication in fish larviculture. J. World Aquac. Soc. 24, 246-261.

Hecht, T., Uys, W., 1997. Effect of density on the feeding and aggressive behaviour in juvenile African catfish, Clarias gariepinus. S. Afr. J. Sci. 93, 537-541.

Il'ina, L.K., 1973. Behaviour of perch (Perca fluviatilis L.) underyearlings of different ecological groups in the progeny of a single pair of spawners. J. Ichthyol. 13, 294-304. 
Jourdan, S., 1999. Influences de facteurs abiotiques, la photopériode et l'intensité lumineuse, sur la survie et la croissance de larves, post-larves et juvéniles de perche commune Perca fluviatilis L. PhD Thesis, Institut National Polytechnique de Lorraine, Nancy, France, 145 pp.

Kaiser, H., Weyl, O., Hecht, T., 1995. The effect of stocking density on growth, survival and agonistic behaviour of African catfish. Aquac. Int. 3, 217-225.

Katavic, I., Jug-Dujakovic, J., Glamuzina, B., 1989. Cannibalism as a factor affecting the survival of intensively cultured sea bass (Dicentrarchus labrax) fingerlings. Aquaculture 77, 135-143.

Kestemont, P., Fiogbé, E., Parfait, O., Micha, J.-C., Mélard, C., 1995. Relationship between weaning size, growth and cannibalism in the common perch larvae, Perca fluviatilis: a preliminary approach. In: Lavens, P., Jaspers, E., Roelants, I. (Eds.), Larvi'95: Fish and Shellfish Aquaculture Symposium, vol. 24. European Aquaculture Society, Ghent, pp. 251-278. Spec. Publ.

Kestemont, P., Mélard, C., Fiogbé, E., Vlavonou, R., Masson, G., 1996. Nutritional and animal husbandry aspects of rearing early life stages of Eurasian perch. J. Appl. Ichthyol. 12, 157-165.

Kestemont, P., Jourdan, S., Houbart, M., Mélard, C., Paspatis, M., Fontaine, P., Cuvier, A., Kentouri, M., Baras, E., in press. Size heterogeneity, cannibalism and competition in cultured predatory fish larvae: biotic and abiotic influences. Aquaculture.

Konstantinov, K.G., 1957. Comparative analysis of morphology and biology of perch, pikeperch, Volga pikeperch of different stages of development. Rep. Inst. Evol. Morph. Anim. 16, 181-236.

Kubitza, F., Lovshin, L.L., 1999. Formulated diets, feeding strategies and cannibalism during intensive culture of juvenile carnivorous fishes. Rev. Fish. Sci. 7, 1-22.

Kucharczyk, D., Mamcarz, A., Kujawa, R., Skrzypczask, A., 1998. Development of cannibalism in larval northern pike, Esox lucius (Esocidae). Ital. J. Zool. 65, 261-263. Suppl.

Lee, C.-S., O’Bryen, P.J. (Eds.), 2001. Advanced Biotechnology in Hatchery Production. Aquaculture, vol. 200, pp. $1-250$.

Li, S.K., Mathias, J.A., 1982. Causes of high mortality among cultured larval walleyes. Trans. Am. Fish. Soc. $111,710-721$.

Loadman, N.L., Moodie, G.E.E., Mathias, J.A., 1986. Significance of cannibalism in larval walleye (Stizostedion vitreum). Can. J. Fish. Aquat. Sci. 43, 613-618.

Meffe, G.K., Crump, M.L., 1987. Possible growth and reproductive benefits of cannibalism in mosquitofish. Am. Nat. 129, 203-212.

Mélard, C., Kestemont, P., Baras, E., 1995. Preliminary results of European perch (Perca fluviatilis) intensive rearing trials: effect of temperature and size grading on growth. Bull. Fr. Pêche Piscic. 336, $19-27$.

Mélard, C., Baras, E., Mary, L., Kestemont, P., 1996a. Relationships between growth, cannibalism and survival rate in intensively cultured larvae and alevins of perch (Perca fluviatilis). Ann. Zool. Fenn. $33,643-651$.

Mélard, C., Kestemont, P., Grignard, J.C., 1996b. Intensive culture of juvenile and adult Eurasian perch (P. fluviatilis): effect of major biotic and abiotic factors on growth. J. Appl. Ichthyol. 12, 175-180.

Nilsson, P.A., Bronmark, C., 1998. Foraging among cannibals and kleptoparasites: effects of prey size on pike behavior. Behav. Ecol. 10, 557-566.

Sakakura, Y., Tsukamoto, K., 1996. Onset and development of cannibalistic behaviour in early life stages of yellowtail. J. Fish Biol. 48, 16-29.

Smily, W.J.P., 1952. Observations on the food of the fry of perch, Perca fluviatilis L. in Windermere. Proc. Zool. Soc. Lond. 122, 407-416.

Smith, C., Reay, P., 1991. Cannibalism in teleost fishes. Rev. Fish Biol. Fish. 1, 41-64.

Spanovskaya, V.D., Grygorash, V.A., 1977. Development and food of age-0 Eurasian perch (Perca fluviatilis) in reservoirs near Moscow, USSR. J. Fish. Res. Board Can. 34, 1551-1558.

Tamazouzt, L., Dubois, J.P., Fontaine, P., 1994. Production et marché actuels de la perche (Perca fluviatilis) en Europe. Piscic. Fr. 114, 4-8.

Thorpe, J., 1977. Synopsis of biological data on the perch Perca fluviatilis (Linnaeus, 1758) and Perca flavescens (Mitchill, 1814). FAO Fish. Synop. 13, 138 pp.

Tsai, C., 1991. Prey density requirements of the striped bass, Morone saxatilis (Walbaum) larvae. Estuaries 14, $207-217$. 
Uematsu, T., Takamori, J., 1976. Social facilitation in feeding behaviour of the medaka, Oryzias latipes: 1. Continuous observation during a short period. Jpn. J. Ecol. 26, 135-140.

van Damme, P., Appelbaum, S., Hecht, T., 1989. Sibling cannibalism in koi carp, Cyprinus carpio L., larvae and juveniles reared under controlled conditions. J. Fish Biol. 34, 855-863.

Vlavonou, R.S., Masson, G., Moreau, J.C., 1999. Growth of Perca fluviatilis larvae fed with Artemia spp. nauplii and the effects of initial starvation. J. Appl. Ichthyol. 15, 29-33. 